\title{
Architecture_MPS
}

\section{Empty Architecture and Empty Urbanism: the Remaking and Reframing on Contemporary Beijing}

lan Ho-yin Fong ${ }^{1}$

How to cite: Ho-yin Fong, I. 'Empty Architecture and Empty Urbanism: the Remaking and Reframing on Contemporary Beijing.' Architecture_MPS, 2016, 8(1): 3. DOI: https://doi.org/10.14324/111.444.amps.2016v8i3.001.

Published: 01 January 2016

\section{Peer Review:}

This article has been peer reviewed through the journal's standard double blind peer-review, where both the reviewers and authors are anonymised during review.

\section{Copyright:}

(C) 2016, The Author(s). This is an Open Access article distributed under the terms of the Creative Commons Attribution License (CC-BY) 4.0 https://creativecommons.org/licenses/by/4.0/, which permits unrestricted use, distribution and reproduction in any medium, provided the original author and source are credited • DOI: https://doi.org/10.14324/111.444.amps.2016v8i3.001.

\section{Open Access:}

Architecture_MPS is a peer-reviewed open access journal. 


\section{Title: Empty Architecture and Empty Urbanism: the Remaking and Reframing on Contemporary Beijing}

\section{Author: Ian Ho-yin Fong}

\section{Architecture_media_politics_society. vol.8, no.3.}

January 2016

Affiliation: The Chinese University of Hong Kong

\section{Abstract}

The paper discusses a collage and montage understanding of modernity and argues that Beijing offers a contemporary simulacrum of the global system of sign values that is epitomized by the new CCTV headquarters and more directly mirrored in the Beijing World Park. In reading Beijing this way, the paper suggests that the city, as well as the global audience to which its spectacle architecture is addressed, is suffering an identity crisis in which our built environment has been reduced to series of signs. It discusses the architecture of the CCTV headquarters, then Beijing World Park as the miniature of Beijing, and finally how the slogan of Beijing Olympics 2008, "One World! One Dream!", helps to read the contemporary architecture in Beijing as a symbol of the city's - and through the city, the government's - view of itself as a new world leader. It begins by placing this argument in a particular social, political, and economic framework - the attempts of the current Chinese authorities to position the Chinese economy, and its major cities, at the heart of the contemporary capitalist economy. These attempts, it is suggested, involve a more or less literal attempt to outstrip the city which throughout the twentieth century epitomized that system, New York. 


\title{
Title: Empty Architecture and Empty Urbanism: The Remaking and Reframing on Contemporary Beijing
}

\author{
Author: Ian Ho-yin Fong
}

Architecture_media_politics_society. vol. 8, no. 3 .

January 2016

\section{The CCTV Headquarters: An Imported Simplified Symbol of a Modern Global City}

A discussion of architecture in Beijing (the iconic city of "socialism with Chinese characteristics") can be equated to New York in its late nineteenthand early twentieth-century forms. In delirious New York, Rem Koolhaas argues that Manhattan was the result of "the conquest of the irrational," or "the conscious exploitation of the unconscious." In this framework, the architectural skyscrapers of New York are defined as the result of the attempt to fulfill a desire for 'phallic power' in order to cover up a form of inferiority complex. It is a definition that we can legitimately consider in analyzing the very different, but similar, example of contemporary Beijing under modern autocratic rule. Both within China and internationally, the Forbidden Palace still serves as the most notable "sign" or "symbol" of the city. As a result, some commentators - and city PR officials - suggest the city can never be associated with contemporary modern cities such as New York. In the framework of this argument, buildings like the CCTV headquarters can be defined as aiming to replace the Forbidden Palace as 'the' globally recognized signifier of China, and thus China's modernity.

Considered in the context offered by projects such as the CCTV headquarters, twenty-first-century Beijing is seen to be broadcasting a piece of news to the world through architectural spectacle. Its message is that the contemporary melting pot and capital of the global market is, or soon will be, Beijing. Other explicit examples of this are clearly evident in city marketing. Sun Dong An Plaza for example, is advertised as comparable to Ginza (Tokyo), Manhattan (New York), and Canary Wharf (London). Some adverts claim that through this plaza, "We [the city of Beijing] Have in Beijing What They Have in New York". ${ }^{2}$ It seems that city promotors consider a simple graphic "cut and paste" job enough to turn Beijing into a global city. ${ }^{3}$ It is an expanded reading of this "cut and paste" approach that this paper applies 


\section{Amps}

to the use of architecture in the city, with buildings from the West's leading architects 'dropped' into its urban fabric in an attempt to transfer meanings and symbolism.

The CCTV headquarters, thus understood, broadcasts a piece of news to American architects that their contemporary architectural dreams can be better fulfilled in contemporary Beijing under the communist dictatorship than it can in the nineteenth- and twentieth-century city of New York. ${ }^{4}$ It is as if the recent period of global recession allowed Chinese communism to position itself as a 'last resort' - a place where the capitalist ethos and economic model could still thrive. In this context, Beijing employs American architectural firms and design practices extensively and even now follows the architectural codes of American capitalism to govern and regulate its development. ${ }^{5}$ It can thus be said to have, literally, taken on the models of New York and presented itself as its replacement as the world's leading "global city."

\section{The Simplification of the City as a Site of Profit and Construction}

Although the CCTV headquarters has become the new landmark of this new twenty-first-century Beijing, the symbolic significance of the Forbidden City is never lost, and cannot be shaken off. ${ }^{6}$ It visually narrates a historical fact that Beijing was developed long before Paris, London, and New York. However, when Beijing is represented by the Forbidden City (which is devoid of local inhabitants, but crowded with world tourists), it is as much misrepresented as it is when we link the city exclusively with the CCTV headquarters. If the Forbidden City is the center of Beijing and used to read and interpret the city, it is, like Tokyo, a city with a center empty of inhabitants. ${ }^{7}$ It thus represents a form of "emptiness" as well as history. The new CCTV headquarters by contrast is a "generic iconic" building representing modernity and global commerce. All of these readings capture only single aspects of the city and Beijing becomes dialectically (mis)represented and de-contextualized if we rely too heavily on it two primary architectural icons to interpret it. The city gets compressed into a postmodern spectacle.

Through these prisms, any understanding of Beijing is simplified. It is a simplification that finds a visual analogy in another, seemingly unrelated, aspect of contemporary China - simplified Chinese characters. The word "love" in the traditional Chinese character is the word “愛”. In the simplified one, it is written as “爱”. What is missing in the simplified one is the word “心” meaning "heart." In the simplified Chinese character, to love, then, may imply to love without heart. ${ }^{8}$ In 1956, the Scheme of Simplified Chinese Characters was promulgated by the PRC government. ${ }^{9}$ The simplification movement aimed at improving low literacy rates which adversely affected the modernization of China. It prioritized practical purposes at the expense of an appreciation for the richness and complexities of Chinese characters. What resulted from this grammatical simplification were a series of possible misrepresentations analogous to those that result from using overly simplistic 


\section{Amps}

architectural statements to represent the city of Beijing and its "modern" status.

This process of simplification for practical reasons, and its concomitant reduction of richness, is something we can trace in ideas developed in quite different contexts in recent history. According to Marshall Berman's reading of Marx, the contribution of the bourgeoisie to modernization was to liberate human capacities, and to unleash human possibilities. However, for Berman, the bourgeoisie closes itself off from their richest possibilities when they commit themselves to making money and accumulating capital as a primary, and sometimes exclusive, goal. In a word, capitalism destroys the human possibilities it creates. ${ }^{10}$ The Crystal Palace, built to house the Great Exhibition of 1851, manifests this through its celebration of "the art of engineering." For Berman, "the activity of engineering, so long as it remains an activity, can bring man's creativity to its highest pitch." "Engineering, then, is "a medium for the self"s development" which affirms "modernization as a human adventure." However, "as soon as the builder stops building, and entrenches himself in the things he has made, the creative energies are frozen." The building becomes "a container for its confinement"; modernization becomes "deadening routines." 12 It was put another way by the narrator in Dostoyevsky's Notes from Underground who discusses the Crystal Palace: "perhaps [man] only likes building it, not living in it." 13

These processes of simplification, the forces that prioritize the practical over the liberating, and an exclusive focus on wealth accumulation, can all be highlighted in an analysis of the forces of modernization now creating the physical form of Beijing. It was also evident in New York a century ago. To Le Corbusier, New York in the 1930s manifest modernization as a human adventure. The city "has such courage and enthusiasm that everything can be begun again, sent back to the building yard and made into something still greater, something mastered!" 14 However, in Le Corbusier's celebration of the courage to start anew, clearly relevant to the Chinese context, focus was placed on the process and excitement of construction and profit. To return to Berman, the completion of the Crystal Palace that is modern Beijing freezes the creative energies and becomes what Berman would defined as a tomb. ${ }^{15}$ It is also a grossly oversimplified and misrepresented representation and understanding of the city, its life and its inhabitants.

\section{Urban Model, Urban Analogy, and Urban Image: Beijing World Park and the City Itself}

The CCTV building then plays its role in the simplification of our readings of Beijing and celebrates process and profit above all else. As Daniel Solomon argues:

Imagine a situation in which 97 percent of the residential fabric of New York and Chicago including the most vibrant neighborhoods were demolished in ten 


\section{Amps}

years and the population is forcibly relocated to sterile new suburbs through a massively corrupt system of expropriation. . . Without any exaggeration, that is exactly what is happening in Shanghai and Beijing today and it is what Rem's building celebrates. ${ }^{16}$

Beyond this however, we can also argue that the CCTV headquarters functions like the Eiffel Tower did for Paris. As discussed by Roland Barthes: the Eiffel Tower is "the symbol of Paris, of modernity, of communication, of science or of the nineteenth century." 17 In Barthes' reading of the Eiffel Tower, however, it is not just a symbol - it both sees and is seen. ${ }^{18} \mathrm{He}$ writes at the beginning of the essay "The Eiffel Tower" "[Guy de] Maupassant often lunched at the restaurant in the tower, though he didn't care much for the food: It's the only place in Paris, he used to say, where I don't have to see it". The Eiffel tower, to Barthes, is the center; Paris the circumference. ${ }^{19}$

Writing of contemporary Beijing, and in reference to towers such as the CCTV headquarters, Roy Ong says, the "brightness" of this tower overshadows its neighorhood; its "beauty" is barbaric. ${ }^{20}$ This spectacle is sparsely populated at night but can be seen, whereas the ordinary dwelling is invisible in the dark; vernacular buildings and the memory of an ordinary city are gradually buried; postmodern amnesia will be the result. Although primarily focused on themselves as icons and symbols then, buildings such as this also have other "urban effects": if we add the concept of the docile subject from Foucault's Discipline and Punish to our layered analysis, we can argue that these skyscrapers "discipline" city dwellers precisely as as docile subjects.

If we imagine a flaneur walking this "society of spectacle" with "Chinese characters" it is reasonable to expect the unconscious implanting of an ideology - or at least an illusion - that economic progress is a priority and that today the totalitarian regime of China is best placed to support it. For this to happen an (ideological) tour guide is not needed. It is enough to be embedded in the spectacle. That said, when we consider how people walk around the city and its principal buildings, there is a tour, of sorts, imposed (ideologically). Many parts of the city are of course, off limits and, in the case of the CCTV building, the official tour of the building is deliberately controlled to ensure our reading of it is based only on signs its controllers and designers want us to see. In the tour around the CCTV headquarters public access is limited to what Koolhaas calls "the loop": a sequence of exhibition spaces, restaurants and viewing areas that climb up one tower, cross the bridge and descend the other. ${ }^{21}$ The tour does not allow access to the center. It controls the media, and exhibits sovereignty. It thus simplifies and controls meaning.

While buildings like these - and the city as a modern commercialized entity itself - control our reading by controlling our movement implicitly, the Beijing World Park is far more explicit. The park, also referred to as "The World", does not require a tourist to move around it as if it were a real space. Its slogan is "Walking around the world without leaving Beijing" and its primary mode of transport is a "world tour" train and, as a result, the 


\section{Amps}

world's architectural landmarks (in miniature) tour around visitor. At the Beijing World Park, the tourist is akin to Ulysses tied to a mast watching icons pass him by through the window frame. ${ }^{22}$ The experience is like watching a montage film and, indeed, the park advertises itself as a "cinematic" experience. ${ }^{23}$ Here, the world is compressed into a spectacle viewed through a window or, to put it differently, getting on the tour train is like reading a (3D) map on a screen.

The experience can also be compared to the map reading of Kublai Kan in Calvino's Invisible Cities for whom possessing a map of his land was a proxy for occupying his kingdom. The relationship between the real world and the visual image then, is upside down ${ }^{24}$ and the reality of the world is reduced to a homogeneous and superficial understanding. Key to this are the processes through which the visitor becomes passive, seeing the world in a simplified series of icons in a detached way. Unable to be a flaneur free to dwell in a place, actively experience it and engage in the unfolding of the complexities of life, they look at, and read simplified, two-dimensional architectural messages. The Beijing World Park then, becomes an intensified version of modern Beijing and its experience and interpretation as, and through, a series of architectural symbols of modernity.

\section{From Symbolic Edifice and City to the Anthropology of Living the City}

The way of seeing created by the Beijing World Park, a form of 3-D "world map," does not represent, but rather creates an image of the world. ${ }^{25}$ It frames our understanding of cities across the globe as places of icons that are collaged together. It is precisely because of this presentation of landmarks as unrelated fragments that it is so ruinous and apt as a way of reading contemporary Beijing. Every connection between these individual icons consists of blank space and is, therefore, anthropologically empty. If we consider the real city of Beijing through analogy to this theme park it becomes possible to also read the spaces between its architectural icons as empty - spaces whose only function is to connect the symbols in an efficient way. If, as appears to be increasingly the case, the city and its spaces are reduced to this, it is difficult, if not impossible, for what Marc Augé would call an "anthropological place" (a place "of identity, of relations and history ${ }^{26}$ ) to exist.

For Augé, an anthropological place is somewhere with lived everyday life experiences "formed by individual identities, complicities of language, local references, and the unformulated rules of living know-how." 27 Hence, it is "a principle of meaning for the people who live in it, and also a principle of intelligibility for the person who observes it." 28 With its unstable and shifting meanings anthropological place resists the visual and verbal simplification that recent political and social policies in China have attempted to enforce. ${ }^{29}$ Different from the "spectacular" Beijing ("the abstract and intentional" one), the "anthropological" (or the "unintentional" 30 ) Beijing is homely, 


\section{Amps}

ordinary, and heterogeneous. Epitomized by the hutong, it can be read as a theatrical stage with no director which, in addition, has no global exchange value, and, hence, cannot be "connected globally." 31 The hutong - having no exchange value - is thus consequently unrepresented, exploited, and even destroyed, by "spectacular" city. It can only survive, it would seem, if it makes an appearance and generates a global demand in the tourist sector. All of this is, for the likes of Rem Koolhaas, seemingly unimportant - a narrative that gets subsumed in the tale of progress. "The Chinese," to him, "love the monumental ambition of projects like the CCTV Headquarters." 32 Such buildings, however, as a product of such monumental ambition, devastate the Old Beijing's interconnected neighborhoods and lives brewed in the hutongs.

If we place this sociological phenomenon within the frames of reference of psychoanalysis, the dyadic relationship between mother and father is broken with the "mother" ("the anthropological place") being abandoned for the city to be placed in the (world) symbolic order in the name of the capitalist "father." The spatial design of traditional Chinese buildings is horizontal, with emphasis placed on harmony with the landscape. ${ }^{33}$ For the city of Beijing to be connected globally means this tradition must be abandoned - buildings must built as high as possible. Such global association and symbolism, operative through height, inevitably results in a local disconnection that leaves the living Beijing destroyed and in ruins, buried beneath the modern edifices of the society of the spectacle. For Manuel Castells, this attempt at global connection through architectural imagery, then, turns a city into something it is not - it makes it "not a place, but a process." 34

\section{Conclusion: "One World! One Dream!"}

At the beginning of Garry Marshall's film, Pretty Woman (1990), a voice is heard saying:

Welcome to Hollywood! Everybody comes to Hollywood to get a dream. What's your dream? What's your dream?

The voice is heard again at the end of the film:

Welcome to Hollywood! What's your dream? Everybody comes here; this is Hollywood, land of dreams. Some dreams come true, some don't; but keep on dreamin' - this is Hollywood. Always time to dream, so keep on dreamin'.

This invitation to dream can be seen as indicative of what is happening in Beijing, and China more extensively, if we consider it alongside the slogan of Beijing Olympics 2008, "One World! One Dream!" If framed in the not too distant rhetoric of the voice in Marshall's film, it can be reworked in an aptly Hollywood sense: 


\section{Amps}

Welcome to Beijing (Olympics)! What's your dream? Everybody comes here; this is Beijing, land of one dream. Dreaming Beijing's dream it can come true, some other dreams never do - this is Beijing.

In contrast to this interpretation of a "one world cultural dream," Ulf Hannerz suggests "a world culture marked by an organization of diversity rather than by a replication of uniformity." 35 Similarly, Ackbar Abbas suggests that the portmanteau phrase "one world culture" be separated. For him, "world culture (globalism) is not the same as one culture (with its implication that everyone has an equal place)." 36 However, unlike these interpretations, and unlike Marshall's voice in the capitalist and individualist context of Hollywood, Beijing does not invite one to dream an individual dream. On the contrary, it invites us to dream the dream of the Chinese political elite - to dream a one world dream represented most obviously by the Beijing Olympics 2008 and, to a less explicit more sustained extent, the architectural industry outlined in this paper. In its city architecture Beijing can be said to be dreaming a past dream of the (Western) world - the accumulation of wealth and power expressed through architecture and cities.

What Beijing welcomes through this may however be the Trojan horse. Beijing is becoming a copy of other world cities and what can be seen in the world can also be seen in Beijing. In this sense, Beijing is the Beijing World Park, "The World" - a theme park, copy, and fake city that operates as the world in miniature. In this miniaturized reconstruction of the world in one city, we can get the postmodern, if not ridiculous, sight of a Starbucks coffee shop in the Forbidden City; we find that worldwide brands can be bought in the city, and that its architecture is a reflection of buildings that could have been copied and pasted from and to anywhere. In this sense, the slogan of the Beijing World Park is fulfilled: "Walking around the world without leaving Beijing." However, it may also be possible to turn this assertion on its head. It is possible in Beijing to say that we see the fake world before we see the real. The "Eiffel Tower" is first seen in the Beijing World Park, before seeing the real one in Paris; and the "original" architecture of West is seen first in the copied and pasted replicas that litter the modern city. In Baudrillard's terms, the fake is the "original" and the real only exists to "confirm" the fake.

In dealing with these issues, Baudrillard puts in doubt the relationship between the original and the fake and, in so doing, questions our notions of identity and the certainties thereof. "Confirmation" is not needed when simulation, which in his words, "feign[s] to have what one hasn't . . . [and] . . . threatens the difference between 'true' and 'false." "37 Seen in these terms, it is perhaps apt to ask whether this ambiguous relationship exists in the context of the Chinese capital today. Is Beijing, the capital of China, also the postmodern capital of the twenty-first century? If the Beijing World Park ("The World") consists of empty spectacles, so does the city itself. The world of iconic buildings that exists in miniature inside the park is fake, but so too is the city - and by extension the world - that surrounds it. Not only does the 


\section{Amps}

collage and montage understanding of modernity offered by the city of Beijing create a contemporary simulacrum ${ }^{38}$ of the global system of sign values, and not only is this epitomized by the new CCTV headquarters, it is directly mirrored in the "Beijing World Park" which reveals with clarity the identity crisis of modern architecture and global cities, reduced as they are to series of signs.

\section{Notes}

1 See Koolhaas, Delirious New York: A Retroactive Manifesto for Manhattan (New York: Monacelli Press, 1994), 235-45.

2 Anthony King and Abidin Kusno discuss this plaza, "On Be(ij)ing in the World: 'Postmodernism,' 'Globalization,' and the Making of Transnational Space in China," in Postmodernism and China, ed. Arif Dirlik and Xudong Zhang (Durham, NC, and London: Duke University Press, 2000), 44-6.

3 King and Kusno discuss how urban and architectural forms can be cut from the particular historic urban experience of some societies and cultures, and "pasted" into another society and culture (47).

4 This can be ironically seen in the title of Peter Chan's recent film, American Dreams in China (2013). Distributor: Edko Films. Production companies: China Film Group, China Film Co., Edko Films, Media Asia Films, Stellar Mega Films, Yunnan Film Group.

5 King and Kusno, "On Be(ij)ing in the World," 49.

6 King and Kusno write, "No high-rise towers are allowed to be visible from the walled courtyards of the imperial palace" (61).

7 This is indebted to Barthes' discussion of Tokyo. See Roland Barthes, "CenterCity, Empty Center," in Empire of Signs, trans. Richard Howard (London: Jonathan Cape, 1983), 30-2.

8 Xia Jinxin, "The Advantages of the Traditional Chinese Characters," accessed June 21, 2012, http://cml.cycu.edu.tw/cml/content $/ \%$ E7\%B9\%81\%E9\%AB $\% 94 \%$ E $5 \% \mathrm{AD} \% 97 \% \mathrm{E} 7 \% 9 \mathrm{~A} \% 84 \% \mathrm{E} 5 \% 84 \% \mathrm{AA} \% \mathrm{E} 8 \% \mathrm{~B} 6 \% 8 \mathrm{~A} \% \mathrm{E} 6 \% 80 \% \mathrm{~A} 7$. The English title is my translation.

9 See Ping Chen, Modern Chinese: History and Sociolinguistics (Cambridge: Cambridge University Press, 1999), 154.

10 Marshall Berman, All That Is Solid Melts Into Air: The Experience of Modernity (New York: Penguin, 1988), 93-6.

11 Berman, All That Is Solid, 243.

12 Berman in his reading of the narrator's comments on the Palace makes such distinction (242-5). On the Palace, he says, "[T]he Palace's builders, far from presenting the building as final and indestructible, prided themselves on its transience: utilizing the most advanced modes of prefabrication, it was built in six months in Hyde Park to house the great International Exhibition of 1851; disassembled in three months when the exhibition closed; and then put together again in an enlarged version halfway across the city on Sydenham Hill in 1854" (237-8). On the Palace, see also Fyodor Dostoyevsky, Notes from Underground, trans. Jessie Coulson (London: Penguin, 1972), 42-3. 


\section{Amps}

13 Dostoyevsky, Notes from Underground, 40.

14 See the title of a section in Le Corbusier, Where the Cathedrals Were White, trans. Francis E. Hyslop, Jr. (New York: Reynal \& Hitchcock, 1947), 44-5.

15 Berman, All That Is Solid, 243.

16 Daniel Solomon, "Whatever Happened to Modernity," in Writing Urbanism, ed. Douglas Kelbaugh and Kit Krankel McCullough (London and New York: Routledge, 2008), 160. The essay was written in response to Koolhaas's "Whatever Happened to Urbanism," New York Times March 1, 1998.

17 Barthes, "The Eiffel Tower," The Eiffel Tower and Other Mythologies, trans. Richard Howard (New York: Hill and Wang, 1979), 4.

18 Barthes says, "The Tower ... transgresses this separation, this habitual divorce of seeing and being seen; it achieves a sovereign circulation between the two functions" (5).

19 Barthes, "The Eiffel Tower," 4.

20 Ong writes, "The CCTV center is a building of barbaric beauty that presides over four city blocks in China's capital, facing off with the towers of corporate capitalism." See Aihwa Ong, "Hyperbuilding: Spectacle, Speculation, and the Hyperspace of Sovereignty," in Worlding Cities, ed. A. Roy and A. Ong (Chichester, West Sussex, and Malden, MA: Wiley-Blackwell, 2011), 216.

21 Nicolai Ouroussoff, "Koolhaas, Delirious in Beijing," New York Times July 11, 2011, accessed November 5, 2003, http://www.nytimes.com/2011/07/13/arts/ design/koolhaass-cctv-building-fits-beijing-as-city-of-the-future.html?pagewanted $=$ all\&_r $=1 \&$.

22 This is indebted to Horkheimer and Adorno's critique of enlightenment in Dialectic of Enlightenment, trans. John Cumming (London: A. Lane, 1972).

23 This is indebted to the title of David Clarke's edited book, The Cinematic City (London and New York: Routledge, 1997).

24 Debord says, "When the real world is transformed into mere images, mere images become real things." See Guy Debord, Society of the Spectacle, trans. Ken Knabb (London: Rebel Press, 2003), 11. "In a world that is really upside down, the true is a moment of the false" (9; emphasis original). "Since the spectacle's job is to use various specialized mediations in order to show us a world that can no longer be directly grasped, it naturally elevates the sense of sight to the special pre-eminence once occupied by touch ..." (11) To Baudrillard, "it is the map that precedes the territory - precession of simulacra - it is the map that engenders the territory ..." See Baudrillard, "Simulacra and Simulations," 169.

25 Such idea is indebted to Borges' short story, "On Exactitude in Science”. See Jorge Luis Borges, Collected Fictions, trans. Andrew Hurley (New York: Penguin, 1999), 325.

26 Marc Augé, Non-Places: Introduction to an Anthropology of Supermodernity, trans. John Howe (London: Verso, 1995), 51 and 52.

27 Augé, Non-Places, 101.

28 Augé, Non-Places, 52.

29 Laurie Langbauer, with reference to Lefebvre, discusses the elusiveness of the everyday. See Laurie Langbauer, "Cultural Studies and the Politics of the 


\section{Amps}

Everyday," diacritics 22.1 (Spring, 1992): 47-65. This is a review essay on Patrick Brantlinger, Crusoe's Footprints and Henri Lefebvre, Everyday Life in the Modern World.

30 This distinction is indebted to Dostoyevsky, Notes from Underground: "Towns can be either intentional or unintentional" (18). He describes St Petersburg as "the most abstract and intentional city" (17).

31 See Manuel Castells, "The Space of Flows," The Castells Reader on Cities and Social Theory, ed. Ida Susser (Malden, MA: Blackwell, 2002), 314-66. He says, "[W] hat is most significant about mega-cities is that they are connected externally to global networks and to segments of their own countries, while internally disconnecting local populations that are either functionally unnecessary or socially disruptive" (337). To Sassen, these cities are called "global cities." "There is no such entity as a single global city[.] . . By definition, the global city is part of a network of cities." Saskia Sassen, "Afterword," in World Cities Beyond the West: Globalization, Development and Inequality, ed. Josef Gugler (Cambridge: CUP, 2004), 373. To Sassen, the term "world city" has the opposite attribute: "it refers to a type of city which we have seen over the centuries[.]" (373) Beijing, I refer to in my essay, to Sassen, may be the global city, and, at the same time, the world city.

32 Rem Koolhaas and OMA, "Beijing Manifesto," Wired 12.08 (August 2004): 120, accessed November 13, 2013, http://www.wired.com/wired/archive/12.08/images/ FF_120_beijing.pdf.

33 See King and Kusno, "On Be(ij)ing in the World," 49-50.

34 Castells, "The Space of Flows," 322.

35 See Ulf Hannerz, "Cosmopolitans and Locals in World Culture," Theory, Culture and Society 7: 237.

36 See Ackbar Abbas, Hong Kong: Culture and the Politics of Disappearance (Hong Kong: Hong Kong University Press, 1997), 14.

37 Baudrillard, "Simulacra and Simulations," 170 and 171.

38 On simulacra, see Jean Baudrillard, "Simulacra and Simulations," in Selected Writings, ed. Mark Poster (Stanford, CA: Stanford University Press, 2001), 169-87. These pages are the excerpts from his book, Simulacra and Simulations, trans. Paul Foss, Paul Patton and Philip Beitchman (New York: Semiotext(e), 1983), 1-13 and 23-49.

\section{Bibliography}

Abbas, Ackbar. Hong Kong: Culture and the Politics of Disappearance. Hong Kong: Hong Kong University Press, 1997.

Augé, Marc. Non-Places: Introduction to an Anthropology of Supermodernity. Translated by John Howe. London: Verso, 1995.

Barthes, Roland. The Eiffel Tower and Other Mythologies. Translated by Richard Howard. New York: Hill and Wang, 1979.

Barthes, Roland. Empire of Signs. Translated by Richard Howard. London: Jonathan Cape, 1983. 


\section{Amps}

Baudrillard, Jean. Selected Writings. Edited by Mark Poster. Stanford, CA: Stanford University Press, 2001.

Berman, Marshall. All That Is Solid Melts Into Air: The Experience of Modernity. New York: Penguin, 1988.

Borges, Jorge Luis. Collected Fictions. Translated by Andrew Hurley. New York: Penguin, 1999.

Castells, Manuel. "The Space of Flows." In The Castells Reader on Cities and Social Theory, edited by Ida Susser, 314-66. Malden, MA: Blackwell, 2002.

Chen, Ping. Modern Chinese: History and Sociolinguistics. Cambridge: Cambridge University Press, 1999.

Clarke, David B., ed. The Cinematic City. London and New York: Routledge, 1997.

Debord, Guy. Society of the Spectacle. Translated by Ken Knabb. London: Rebel Press, 2003.

Dostoyevsky, Fyodor. Notes from Underground. In Notes from Underground/The Double, translated by Jessie Coulson. London: Penguin, 1972.

Hannerz, Ulf. "Cosmopolitans and Locals in World Culture." Theory, Culture and Society 7 (1990).

Horkheimer, Max, and Theodor W. Adorno. Dialectic of Enlightenment. Translated by John Cumming. London: A. Lane, 1972.

King, Anthony D., and Abidin Kusno. 'On Be(ij)ing in the World: 'Postmodernism,' 'Globalization,' and the Making of Transnational Space in China.” In Postmodernism and China, edited by Arif Dirlik and Xudong Zhang. Durham, NC, and London: Duke University Press, 2000.

Koolhaas, Rem. Delirious New York: A Retroactive Manifesto for Manhattan. New York: Monacelli Press, 1994.

Koolhaas, Rem and OMA, "Beijing Manifesto." Wired 12.08 (August 2004): 120. http://www.wired.com/wired/archive/12.08/images/FF_120_beijing.pdf. Accessed November 13, 2013.

Langbauer, Laurie. "Cultural Studies and the Politics of the Everyday." diacritics 22.1 (1992): 47-65.

Le Corbusier. Where the Cathedrals Were White. Translated by Francis E. Hyslop, Jr. New York: Reynal \& Hitchcock, 1947.

Lefebvre, Henri. The Production of Space. Translated by Donald Nicholson-Smith. Oxford: Blackwell, 1991.

OMA. "CCTV - Headquarters, China, Beijing, 2002." http://www.oma.eu/projects/ 2002/cctv-\%E2\%80\%93-headquarters. Accessed November 6, 2013.

Ong, Aihwa. "Hyperbuilding: Spectacle, Speculation, and the Hyperspace of Sovereignty." In Worlding Cities, edited by A. Roy and A. Ong. Chichester, West Sussex, and Malden, MA: Wiley-Blackwell, 2011.

Ouroussoff, Nicolai. "Koolhaas, Delirious in Beijing." New York Times, July 11, 2011. http://www.nytimes.com/2011/07/13/arts/design/koolhaass-cctv-building-fitsbeijing-as-city-of-the-future.html?pagewanted=all\&_r=1\&. Accessed November 5, 2003.

Pretty Woman. Directed by Garry Marshall. Burbank, CA, 1990; DVD, Touchstone Home Video, 2000. 


\section{Amps}

Sassen, Saskia. "Afterword." In World Cities Beyond the West: Globalization, Development and Inequality, edited by Josef Gugler. Cambridge: CUP, 2004.

Solomon, Daniel. "Whatever Happened to Modernity." In Writing Urbanism, edited by Douglas Kelbaugh and Kit Krankel McCullough. London and New York: Routledge, 2008).

Xia, Jinxin. "The Advantages of the Traditional Chinese Characters." http://cml.cycu. edu.tw/cml $/$ content $/ \%$ E7\%B9 $\% 81 \%$ E9 $\%$ AB $\% 94 \%$ E5\%AD $\% 97 \%$ E7 $\% 9 A \% 84 \%$ E5 $\% 84 \%$ AA $\%$ E8\%B6\%8A\%E6\%80\%A7. Accessed June 21, 2012. 